\title{
In Defence of British Politics: The Past, Present and Future of the Discipline
}

\author{
Peter Kerr ${ }^{1}$ and Steven Kettell ${ }^{2}$ \\ ${ }^{1}$ Department of Political Science and International Studies, European Research Institute, \\ University of Birmingham, Birmingham B15 2TT, UK. \\ E-mail: p.kerr@bham.ac.uk \\ ${ }^{2}$ Department of Politics and International Studies, University of Warwick, Coventry CV4 7AL, \\ UK. \\ E-mail: s.kettell@warwick.ac.uk
}

In recent years the study of British politics has come under increasing pressure from a variety of developments within academia, most notably a growing trend towards analyses which take the international arena as the main focus of inquiry. This article argues that such changes have had a detrimental effect upon the status and cohesion of the study of British politics as a self-contained discipline, but that the recent decline of academic interest in 'British politics' has also been accelerated by the failure of British politics' scholars themselves to overcome the historical problems associated with the Westminster model. As such, this article traces the evolution of British politics as a field of study, and highlights some of the main challenges that it presently faces. Primarily, these are based around a lack of disciplinary coherence, an insufficient integration between theoretical and empirical, as well as historical and contemporary analyses, and an inadequate conceptualisation of continuity and change.

British Politics (2006) 1, 3-25. doi:10.1057/palgrave.bp.4200004

Keywords: British politics; Westminster model; historical legacy; theoretical developments; contemporary problems

\section{Introduction: Whither 'British politics'?'}

In recent years the study of 'British politics' has been destabilised by a variety of trends that have threatened to undermine its status and cohesion as a selfcontained academic field. Under growing pressure from developments such as the progressively differentiated nature of political science itself, and from changes within the British higher education system (most notably the RAE process), the study of British politics has declined from its erstwhile position as a core area of analytical concern within British universities, to a position whereby it is increasingly regarded as a poor cousin to a number of specialisms which take the international arena as their main focus of inquiry. Against a backdrop of growing global interdependency, academic diversity, and 
theoretical sophistication, the view that the study of 'British politics' still has a central role to play in the current and future academic climate is not one that resonates loudly throughout many contemporary political science departments.

It is perhaps unsurprising then that this article, which is designed to help launch the only journal devoted specifically to promote the study of British politics, should find us in a somewhat defensive mood. While to some, the need for such an outlet might appear as a self-evident and long-overdue necessity, the idea of launching the journal was initially met with a degree of scepticism from some of our colleagues. Amidst the predictable charges of 'parochialism' from various quarters, one observer pointedly remarked to us that the market, and hence the potential for such a journal, would be limited given that there were now only a 'handful' of academics still working within the field of 'British politics'.

This view, that focusing on the politics of Britain is akin to having mistakenly hopped onto the wrong disciplinary bus, is one that we have encountered on a number of occasions. Working within an increasingly competitive and ever-more variegated academic environment, replete with a burgeoning array of specialists in 'international relations', 'international political economy', 'comparative politics', 'European studies', 'global governance', and so on, those of us still operating under the banner of 'British politics' can sometimes feel as if we belong to a small band of old school crackpots who still believe the earth to be flat, while everyone else has sailed off to discover new lands far beyond the horizon. ${ }^{2}$ Indeed, the feeling of having been somewhat left behind is further compounded by the general dearth of British politics posts advertised in the columns of the academic jobs pages, in stark contrast to the specialisms listed above, and by the marked lack of undergraduate courses that are designed to teach British politics in a holistic and inclusive, as opposed to a circumscribed and partial manner. Of the 23 university departments specialising in 'politics and international relations' that were awarded either a '5' or a '5-star' rating in the 2001 Research Assessment Exercise, only 14 (i.e. less than two-thirds) offered courses at levels 1-3, which explicitly purported to examine British politics in anything like a wide-ranging and comprehensive manner. In contrast, the courses in British politics that were offered by most departments focused instead on particular aspects and issues within the field, such as regional issues, public policy-making, and 'contemporary' (typically post-Thatcher) developments. ${ }^{3}$

In addition to this, the RAE process itself has also imposed a series of constraints upon British politics scholars. Chief among these is its arbitrary and hierarchical distinction between national and international reputation (often narrowly defined as one's ability to make it into the pages of an American journal), with the overall process being justified on the grounds of highlighting the more enlightened elements of the academic community, and of 
preventing the so-called 'deadwood' from draining away the increasingly precious resources of the higher education sector. One effect of this, however, has been to apply an increasingly pernicious (though largely unacknowledged) degree of pressure upon scholars to distance themselves from studying the politics of a national, regional, or local political space. If one's specialist area happens to be, for instance, the politics of British local governance, then the chances of making it into the realms of international academic stardom are likely to be a lot more limited in scope than they are for someone who has chosen to devote their energies to studying the inherently grander, and far more fashionable subject matter, of 'global' governance.

All of this is more than a matter of the usual 'sour grapes' from the disgruntled. Rather, it seems paradoxical to us that, when we take a closer look at the work of many of our colleagues in British political science departments who would label themselves 'comparativists', 'Europeanists', or 'globalisation' experts, many of these appear still to use Britain as their main point of reference. Indeed, on an even closer examination, much of this work appears to be directed specifically towards making the point that local, regional, and national politics remain as important as ever and should not be neglected by an overemphasis upon the global sphere.

Furthermore, the growing fragmentation of political science into a series of increasingly distinct and separate disciplinary realms over the last two-and-ahalf decades has also had a detrimental impact upon the study of British politics. Driven in part by the lack of a specialist research outlet, academics working within the field have had to present their research for publication in periodicals that have not been designed to promote the notion of 'British politics', and have thereby been increasingly forced to skew their submissions towards the interests of other disciplines and subject areas. The result of this has often been to restrict the study of British political issues to a comparative analysis alongside developments in other countries, or to reduce it to a mere case study designed to showcase the efficacy of theories from other corners of political science (such as international relations or public choice modelling), or areas of broader thematic concern (such as the nature of Parliamentary systems in general). The overall effect has been to further erode the internal cohesion of 'British politics' as a distinct and clearly delineated field of study, and to add further to the prevailing sense that its day has now largely been and gone. To those of us who refuse to accept the limitations of this trend, however, the growing idea within the British academic establishment that studying the politics of Britain should now be considered somewhat passé seems to be both absurd and misguided. Indeed, our own experience of working within the field has highlighted this in two key ways. Firstly, there remains an extremely high level of demand from students (both domestic and international) to engage in the study of British politics, even at a time when the marketisation of higher 
education and the increasingly competitive nature of the graduate job-market has encouraged students to be more discerning about their choice of courses and modules. Secondly, the majority of scepticism relating to the establishment of a British politics journal has derived from academicians who view themselves as being external to the field itself. In a notable contrast, the response of those from within the British politics community has been overwhelmingly positive, and the high level of support and goodwill that we have received from British politics specialists throughout the course of the project, thus far, has greatly eased its passage from conception to fruition.

Nevertheless, although up to this point we have been inclined towards defending the status of the discipline, the main argument presented here is that if British politics is to regain a strong foothold as a field of study within a rapidly changing academic environment, then British politics specialists themselves must adopt a greater reflexivity towards the methods and approaches they take towards their subject matter. Indeed, the starting point for this needs to be the very definition of what constitutes the study of British politics itself. For far too long, the discipline has suffered from the deficiencies of the so-called 'Westminster model' and its central concern with examining the narrow mechanics of British central government. Admittedly, this approach has been widely acknowledged as being increasingly unsustainable in recent years, and many scholars have started to develop more sophisticated theoretical perspectives and to incorporate a wide range of new debates (such as the role of multi-layered governance and the impact of the international environment), yet these developments have failed to produce the kind of theoretical and methodological advances that have been seen in other branches of political science. As a result, although the focus of British politics may have broadened significantly in recent years, many authors continue to retain a narrowly constructed sense not only of what comprises 'the political' but also of the most appropriate means for its analysis.

To a large extent, this problem stems from the dominant tradition of Whiggish developmentalism within British political studies (itself a legacy of the Westminster model), replete with its anti-intellectual aversion to theoretically informed debate. Having failed to attract the sustained attention of those from more critical and theoretically aware perspectives, the result has been that British politics scholars have tended to produce little more than highly static, overly empiricist, and largely descriptive accounts of formal institutional processes and political behaviour, focusing on debates such as the relationship between the Prime Minister and the Cabinet, the role of the civil service, and the workings of Parliament. In short, having failed to cast off its historical inheritance, and having continued to be defined by those within and beyond the field alike as an area of study equated largely with the analysis of central government, one of the main problems facing the study of British 
politics at the present time lies not with its 'parochial' focus on Britain per se, but with its overly circumscribed conception of, and its theoretically underdeveloped approach towards, its own subject matter. In order to understand why this has been the case, though, requires a look at the evolutionary contours of the field itself.

\section{The Origin of the Species}

Historiographically speaking, the origins of British politics as a field of study can be most usefully said to date from the latter third of the 19th century. Set within a social context in which pressures for a democratisation of the British state were becoming increasingly intense, a number of scholars set out to detail, in highly normative terms, an interpretation of the internal machinery of Britain's central government, highlighting its beneficient and advantageous nature in terms of the provision of economic prosperity and political stability. Headed by the leading trio of Bagehot (1867), Dicey (1885), and Jennings (1936), such scholars collectively laid the foundations of what would later become known as the 'Westminster model' of British political life. ${ }^{4}$

The central features of this model are by now so well known that they are barely worth recounting. In essence, the British polity was conceived as a unitary state, founded on the cornerstones of Parliamentary sovereignty, Cabinet government, individual ministerial accountability, and a neutral civil service. Taken together, this offered a distinctly narrow view of 'the political' (and hence of the appropriate subject matter for inquiry), aligned with a largely static and fundamentally benign impression of Britain's central political institutions and processes. At its core, this was based on an intrinsically Whiggish conception of the political order dating from the Glorious Revolution of 1688, maintaining that this had bequeathed the nation a series of balanced, harmonious, and yet flexible constitutional arrangements, which had enabled it to adjust to social, political, and economic change in a gradualist and evolutionary manner, and which had thereby enabled it to avoid the kind of upheavals and revolutionary politics that had been seen in other states.

True, not all authors subscribed to all aspects of this model. Some, such as Low (1907), Lowell (1908), and Muir (1930), for instance, highlighted the growing influence of political parties upon the workings of Parliament, while others, such as Laski $(1933,1938)$, staunchly contested the view that Britain's political institutions were inherently stable, and suggested that a period of sharp economic dislocation might precipitate the emergence of a more authoritarian form of rule. Yet, such dissenting voices remained marginal to the early development of British political studies, and proved unable to dislodge the constitutional myths that were being erected by their more 
prominent counterparts. In any case, early scholars also remained united in one important respect, namely their almost-exclusive focus on the institutions and processes of central government, and in their regard for 'the political' as being wholly coterminous with formal procedures within the public realm.

A further defining characteristic of these early studies was the overwhelmingly descriptive and atheoretical form of their narratives. In one sense, this was hardly surprising. The study of 'politics' itself was not yet considered by the social sciences to be a self-contained field of inquiry set apart from the dominant studies of history, law, economics, and philosophy, while politics' scholars themselves hailed largely from the ranks of historians, journalists, lawyers, and practitioners. Nevertheless, the fact that these formative examinations into the British polity were constructed upon the methodological foundations of an essentially moral and inductive, as opposed to a systematically theorised process of conceptual inquiry, was to have important implications for and during the course of its future development.

The narrowly circumscribed view of 'the political', which characterised the pre-1945 era of British political studies became gradually widened after the Second World War. Driven by the broader conception of political activity that had been fostered by the wartime expansion of the state, by the extensive blurring of the public and the private spheres that this had necessitated, and by the post-war rise of collectivism (notably marked by the construction of the welfare state and the commitment to full employment), the realm of 'the political' was no longer thought to be confined to the formal mechanics of the constitution, but was now seen to include a wider range of political relations, taking account of the increasing size and scope of the civil service, the activities of the main political parties, and the growing influence of pressure groups (especially the 'peak organisations' of the Trades Union Congress and the Confederation of British Industry). Consequentially, the central themes and issues of British political studies themselves became somewhat broader, ranging from analyses of the relationship between the Cabinet and the Prime Minister (e.g. Mackintosh, 1963, 1977; Heclo and Wildavsky, 1974); the role of political parties (e.g. Mackenzie, 1955); the relationship between ministers and civil servants (e.g. Headey, 1975); and the role of pressure groups within the policy-making process (see Truman, 1951; Beer, 1965; Wilson, 1977; Middlemas, 1979).

Yet, despite this adoption of a broader view of political life, the subject matter of British politics itself continued to be rooted within the organising perspective of the Westminster model. The central issues of analysis remained focused on the various component parts of the British political system and on the way in which these interacted with the core institutions and processes of the British state, while most scholars, despite the growing professionalisation of political science generally, retained an aversion to theoretical analysis and a 
commitment to inductive as opposed to more systematised modes of inquiry. Notwithstanding the seeping influence of North American political science, which began to inject a nascent stream of positivist analyses into the field, the overall result was to perpetuate the essentially descriptive and fundamentally Whiggish interpretations of the pre-war era. Insofar as mainstream studies of British politics were concerned, the emphasis thus remained firmly on the historical continuity of the system, on the existence of a consensual political culture, and on the ostensible virtues of the British constitution (see, e.g., Birch, 1964; Beer, 1965).

\section{Crisis, Thatcherism, and beyond}

During the 1960s and 1970s, buoyed by a large expansion in the British higher education sector, the field of British politics enjoyed a period of heady growth. At the same time, however, the central tenets of the Westminster model came under an increasingly sustained degree of pressure as Britain also settled into a long-drawn series of political and economic crises, marked by rising social discontent and by a growing recognition of its long-running relative economic decline. Alongside the more traditional debates of the period, there henceforth emerged a growing concern among scholars to discover the causes of the 'British disease', and to prescribe the most appropriate remedy for administration. To many authors, the origins of the crisis were to be found in the collectivist ethos and pluralist democracy that had prevailed in Britain since 1945. This was seen to have usurped the central institutions and processes of the British political system, and to have produced a rise in expectations and a proliferation of societal demands far beyond what the government could realistically be expected to fulfil. As such, the cure for Britain's malaise was often posed in terms of a re-drawing of the post-war settlement to enable a reassertion of strong and effective government (see, e.g., King, 1975; Brittan, 1977; Richardson and Jordan, 1979; Rose, 1979; Beer, 1982; Birch, 1984).

For many other commentators however, a key source of Britain's difficulties was to be found precisely in the central institutions and processes of its political system. In contrast to the apparent virtues of continuity and stability hailed by supporters of the Westminster model, a number of scholars began to argue that such attributes were now acting as an impediment to Britain's further economic and political modernisation. As a result, a variety of progressive reforms to its political arrangements, involving changes to the civil service, Parliament, and the electoral system, were seen to be required if Britain's atrophy was to be reversed (see, e.g., Gamble, 1974; Finer, 1975). The onset of Britain's political and economic crisis also offered rich pickings for more critical scholars, increasingly spurred on by the growing popularity of Marxist and neo-Marxist ideas. Chief among these, many analysts now sought to draw attention to the 
enduring and regressive nature of an entrenched elite operating at the centre of Britain's political and economic institutions. Typically, this centred around the financial sector of the City of London, coupled with its highly closed and stratified system of public-school recruitment, and its close historical and institutional linkages to the Bank of England and the Treasury. In sum, the prevalence of a ruling elite acting in its own, and predominantly short-term self-interests, was considered to be the central barrier to Britain's social, democratic, and industrial development, necessitating more wholesale remedial measures based on a deeper reorganisation of British society (see Guttsman, 1963; Nairn, 1964, 1981; Anderson, 1964; Miliband, 1969; Coates, 1980; Hobsbawm, 1981).

Nevertheless, while this generalised wave of academic criticism was now sufficiently forceful to undermine the utility of the Westminster model as the best means of understanding political developments in Britain, the underlying and long-standing deficiencies of academic inquiry remained soundly intact. Despite the progressively broadening notion of 'the political', despite the application of more methodologically sophisticated modes of research, and despite highlighting an array of difficulties within the British political system, critical analysts and defenders of the faith alike continued to focus their attention primarily on the core institutions, processes, and actors operating within and around the apex of the British state. As such, the boundaries of British political studies remained tightly circumscribed, with no provision of any coherent organising perspective with which to replace the Westminster model. While gunslinging academics had now fatally wounded the interpretations of Bagehot and Dicey, the ghosts of their pre-war ancestors continued to stalk the halls of the academy.

In many ways then, the election of the Conservative government in 1979 marked a watershed for the field of British politics. As the Thatcherite project to reform the state and re-draw the boundaries between the public and private spheres gained momentum, the political and economic changes this produced engendered (somewhat paradoxically) another broadening of 'the political', and gave a strong impetus to academic research into British political studies. The central effect of this was to pave the way for a proliferation of new discourses, and to foster a range of more sophisticated theoretical developments within the field. Alongside ongoing debates, such as the inquiry into the 'exceptional' (i.e. City-dominated) character of Britain's political economy (e.g. Ingham, 1984; Fine and Harris, 1985), the enduring dominance of its political elite (e.g. Sampson, 1982, 2004; Scott, 1991), the nature of its political and economic decline (see, e.g., Gamble, 1981, 1994; Wiener, 1981; Collins and Robbins, 1990; and later, Coates, 1994; and also English and Kenny, 2000), as well as the ever-present analysis of its institutional mechanics (e.g. King, 1985; Robins, 1987; Kavanagh, 1990), new developments also now began to take 
root and flourish. These were to be found in the rich and variegated analyses of 'Thatcherism' itself (such as Hall, 1979; Hall and Jacques, 1983; Bulpitt, 1986; Gamble, 1988; Jessop et al., 1988; Overbeek, 1990), and in the increasing attention being directed towards meta-theoretical issues such as the relationship between structure and agency, and the notion of conceptualising continuity and change (see, for instance, Giddens, 1985; Hall, 1986; Jessop, 1990).

In effect, the Thatcher governments compelled the field of British politics to reconsider a number of its central suppositions. Importantly, the swathe of Thatcherite reforms appeared to disrupt the notion of a single, unilinear path of British development. Whereas the former period of the so-called social democratic reform could be reconciled with the Whig view of a political tradition gradually evolving towards an expansive and progressive view of democracy and liberty, Thatcherism harked back to a period of Victorian values and a relative retrenchment of British democracy from its heyday during the post-war period. In sum, the Thatcher government's obsession with 'rolling back the frontiers of the state' via the deregulation, privatisation, and marketisation of public services presented a further challenge to the centrality of the Westminster model, as well as long-held views about the unitary character of the British state, the relationships between Prime Minister and Cabinet, the executive and the civil service, and central and local government.

These developments have also continued apace throughout the postThatcher era. As the governments of John Major and Tony Blair have sought to broaden and deepen the neo-liberal project of state restructuring, and as the interdependency of the global environment has become an area of increasingly evident concern, a range of new debates addressing themes such as the impact of globalisation (Watson, 1999), European integration (Bulpitt, 1996; George, 1998; Geddes, 2004), as well as the internal effects of multi-layered governance and constitutional reform (e.g. Bogdanor, 1999; Morrison, 2001; O’Neill, 2004) have helped to stretch still further the boundaries of what is now considered to represent 'the political'.5 In conjunction with these developments, the contemporary period has also witnessed the formal supplanting of the Westminster model with that of the 'governance' thesis, expressed most coherently in the Differentiated Polity model, as the dominant organising perspective within the field of British politics. In contrast to the old monolithic view of the British political system perpetuated by the Westminster model, this offers a view of British politics as one based around the notions of policy networks, power dependencies, and exchange relationships, all set within the context of an increasingly hollow state, and involving a complex web of actors stretched out far beyond the centre (see Marsh and Rhodes, 1992; Rhodes, 1997; Marsh, 1998; Smith, 1999; Richards and Smith, 2002; Bevir and Rhodes, 2003). 


\section{Contemporary Theories of Change}

Beyond the governance model, with its primary focus on the shifting nature of policy-making within the British state, the field of British politics has, in recent years, also witnessed a number of theoretical advances concerned with tackling a set of broader meta-theoretical issues, and with providing diachronic as opposed to traditional synchronic analyses. Prominent among these have been the emergence of neo-institutionalist approaches, which have attempted to extrapolate at a more abstract and theoretical level, insights into such issues as the relationship between actors and their situational context, the role of ideas in generating institutional change, the temporality of change itself, and the extent to which change is governed by processes which are contingent or path dependent (e.g. Hall and Taylor, 1996; Hay and Wincott, 1998).

Although these approaches have generally been inspired by North American political scientists, they have, albeit to a limited extent, left imprints on analyses that are specific to British public policy. One of the most influential legacies from this type of approach, for example, can be found in the idea of 'paradigm change' inspired by Peter Hall (1993). Authors such as Hay (1996, 1999) and Heffernan (2001) have attempted to apply this idea to their analyses of institutional and policy change in post-war Britain, where the concept (set within a 'punctuated evolutionary' conception of British political dynamics) has been utilised to explain the overall shift since the Second World War from a social democratic to a neo-liberal policy paradigm. In terms of the analysis of change, this conceptualisation goes a long way in offering an alternative to the historicist and teleological tendencies that are inherent within traditional approaches to British politics. Instead, the emphasis is placed upon the role of ideas in generating periods of institutional and policy change, while continuity is accounted for in terms of the embeddedness of dominant sets of ideas and discourses over particular time frames.

A related approach is the growth of interest in neo-evolutionary accounts of change, where various authors have sought to generate theoretical insights which build upon neo-evolutionary work in other disciplines such as economics, sociology and organisational theory (see John, 1998, 1999; Ward, 1989, 1997; Kerr, 2001, 2002; for a critique, see Curry, 2003; Kay, 2003; Dowding, 2000). Explicit within such approaches is an attempt to create a theoretical break with traditional teleological and reductionist conceptions of evolutionary change, implicit within the traditional approach to British politics. As with neo-institutional literatures, the emphasis is upon the temporality of change, and the various mechanisms which generate the relationship between processes of change which are both path-dependent and contingent. 
Yet, while such approaches have attempted to move beyond the narrow empiricist, and overly descriptive tendencies that have dominated the discipline traditionally, much of this work suffers from two main difficulties. Firstly, although these developments are generic to political science more broadly, the large majority of studies remain limited to theoretical analyses, and presently lack any firm empirical application to British political life. Secondly, such approaches also tend to be confined to a few key authors, and thereby reside only at the fringes of the wider academic debate about British politics. In contrast, the overwhelming preference for most scholars has been to stick to more traditional methods, approaches, and conceptual tools.

While the field of British politics still has some way to go to match some of the more sophisticated theoretical advances of disciplines such as sociology and international relations, one distinctly deliberate attempt at overcoming this problem has been the effort to introduce critical realist perspectives into conventional debates about change in post-war Britain (see Marsh et al., 1999; McAnulla, 2006). Building upon the work of Bhaskar (1986) and Archer (1995), these post-positivist accounts are predicated upon a belief that decisionmaking is shaped by underlying structural influences, which are not always directly observable, and that any study of power in Britain thus requires a degree of analytical interpretation. Importantly, such accounts seek to direct attention towards the social and economic context in which governmental decisions are played out, thereby avoiding the narrow focus upon formal governmental structures and the restricted definition of 'the political', which has plagued traditional narratives.

The most self-confident and influential attempt at a post-positivist approach to date, however, has come in the form of 'interpretivist' political science. Here, Bevir and Rhodes have been particularly prominent in generating a wholesale critique of the problems associated with traditional approaches to British politics, and in offering in their place a deliberate attempt to move beyond both the Westminster model and the teleological historical narrative inherent within it. It is to this latter problem that Bevir and Rhodes pay particular attention, with a large part of their critique being aimed at the idea of a strong British political tradition, which influences and determines contemporary power relations. Within interpretivist accounts, change is perceived of as being both highly contingent and multi-directional, depending upon actors' particular interpretations of the context within which they operate and the 'dilemmas' they face. According to such accounts, the development of British politics has been shaped by a number of competing traditions, which present political actors with a complex system of 'webs of belief'. When faced with particular dilemmas, decision-makers are selective about which particular webs of belief to draw upon, depending largely upon their interpretations of the context and the types of dilemmas they face. This puts an emphasis upon the researcher to 
14

conduct qualitative analysis in order to deconstruct and interpret the types of factors that shaped a particular response to a policy problem. In this sense then, interpretivist approaches stress the need for both qualitative over quantitative analyses, and represent a departure from the traditional assumption that Britain has had a single, unilinear developmental trajectory, and that this has had a causal relationship in shaping contemporary trends.

\section{Prevailing Problems}

While the types of theoretical debates and approaches highlighted above represent a useful attempt to move beyond the confines of traditional British political studies and to broaden the focus of the discipline, both in terms of the subject matter which is to be examined as well as the theoretical tools that are available to be used, many of these remain in a state of relative infancy, have thus far attracted attention from a relatively small number of authors, and remain solidly confined to the margins of academic discussion. As such, despite these developments, the discipline as a whole has still largely retained its strong empiricist bias, with few authors willing to demonstrate any type of theoretical edge or ambition. Indeed, as McAnulla (2006, 3) remarks: 'often theory is regarded as something of a side-show, to be picked up where useful but non-essential next to the study of actual political events and processes'. In contrast, while McAnulla is highly critical of the lack of theory, Marshall (1999, 284-285) provides the more widespread, and perhaps complacent, view, that good detailed description is more than an adequate substitute for theorymaking:

The explanatory problem is simply that of describing relevant segments of the system in sufficient detail to expose what happens or happened. When we know enough about what happens, we know why... when it comes to assessment or prescription no deep justificatory theories are normally required. We know already what the relevant moral and political values are - democracy, liberty, equality, due process, rule of law and the like.

Such a statement reflects heavily the historical tendency within the field towards a Whiggish confidence in the efficiency of the workings of the constitution and the Burkean defence of incremental, piecemeal change. In short, it leads us to question the extent to which the discipline has, in reality, successfully managed to shed the vestiges of the Westminster model and the traditional problems that this has engendered. Furthermore, despite its deliberate attempt at superseding the Westminster model, the presently dominant governance thesis, with its implicitly Whiggish narrative of a shift 
within the British state from a hierarchical, bureaucratic, and unitary system of elite government towards a more expansive and pluralised system of democracy and representation, has also arguably embedded much of the legacy of the former. Indeed, despite its interpretivist roots, this continues to offer little more than a traditionally descriptive elite-pluralist model of British politics, which continues to focus upon core institutions, actors, and processes. Despite introducing a range of new subject matter into the field of play, the central questions of governance studies have remained focused on the core policy-making processes of the British state, and on the ways in which these have been affected by, and managed within, an increasingly diverse and complex political arena. As such, the central objective has essentially been to describe and demystify formal political mechanics that ultimately have either a direct or an indirect relationship to Westminster itself.

And opponents of the governance thesis too have been relatively circumspect in their treatment of such issues. While many critical accounts of the British political system have sought to highlight its various institutional and procedural deficiencies in terms of democratic practice (e.g. Judge, 1993, 2004; Weir and Beetham, 1999, 2002), others have sought to challenge the claims made by governance scholars on their own terrain, contesting their assumptions of an increasingly pluralistic polity by highlighting the asymmetric nature of power relations that continue to exist between the core executive and other actors (see Marsh et al., 2001, 2003).

While this latter example does, indeed, attempt to situate the analysis of power within a wider historical and contextual setting (thereby highlighting issues of structural inequality that are often neglected in more conventional approaches), the empirical application of alternative theoretical approaches has, in general, remained somewhat limited. Academics working from within rational choice and feminist approaches, for example, have also tended to focus on specific aspects of the political system (such as the nature of the core executive, and the under-representation of women in Parliament); interpretivist analyses have yet to make any real headway into the field of British politics, while critical realists and Marxists alike have displayed a marked proclivity towards ever-greater theoretical refinement, and a preoccupation with broader concerns such as the nature of 'the state' and its relationship to various societal institutions and processes, as opposed to the more mundane study of British politics per se. In sum, despite the emergence of new theoretical developments and a further broadening of 'the political' during recent years, attempts to go beyond the core institutions, processes, and actors of the British state in order to examine its underlying sources of power and inequality have remained distinctly limited. In this sense then, it is arguable that while the notes of inquiry have changed, the analytical song of British political studies has remained very much the same. 
In addition to this, while the British political system writ large has become increasingly differentiated since the time of the Thatcher governments, so too has the study of British politics itself. The result of this has been to produce a growing fragmentation of the academic field. While the diffusion of political inquiry into ever-more dispersed areas and aspects of the British polity has been another welcome and much needed progression, this growth in diversity has also led to a plethora of disparate approaches and terms of reference that are specific to particular sub-fields and areas of expertise. In effect, this has led to the creation of a series of 'island mentalities', entrenching the existing divisions within the field, and further subdividing the discipline into a series of specialised studies of particular institutions, processes, and behaviours that operate within conceptual discourses and methodological approaches that are specific to that area itself.

Moreover, at the same time as this fragmentation has served to undermine the coherence and identity of the field of British politics, it has also hampered its theoretical development. In many ways, the growing compartmentalisation of the field has made it harder for new theoretical and methodological developments to circulate among the scholarly community. Importantly too, this has also contributed towards a pronounced bifurcation between empirically and theoretically oriented research. While empirical studies have predominantly tended to focus upon institutionalist and policycentric analyses such as those relating to questions of constitutional reform, economic management, social policy, and so on, the scope of theoretical research has tended to focus on broader thematic issues, such as metatheoretical debates and concerns. As a result, this separation has tended to encourage research that is either atheoretical, empirical, and descriptive, or which is excessively theoretical at the expense of producing strong empirical evidence.

A key result of this is that despite the growing diversity of studies into the British polity, the study of 'British politics' overall has continued to remain theoretically underdeveloped. Indeed, despite its ever-broadening conceptualisation of 'the political', the focus for much mainstream research activity remains primarily centred around traditional debates concerning the individual aspects of the British political system. Among these include old favourites such as the electoral system (e.g. Norris, 1995; Watts, 2000); the civil service (Drewry and Butcher, 1988; Barberis, 1996; Bogdanor, 2001); the role of political parties and the party system (Garner and Kelly, 1998; Ingle, 2000; Webb, 2000); the role and influence of pressure groups (Baggott, 1995, 2000; Grant, 1995, 2000); as well as the perennial chestnut concerning the relationship between the Prime Minister and the Cabinet (Foley, 1993, 2000; Hogg and Hill, 1995; Rhodes and Dunleavy, 1995; Kavanagh and Seldon, 1999; Hennessy, 2000). 


\section{Forward Thinking}

While seeking to highlight the key problems and challenges that are faced by contemporary scholars of British politics, the argument outlined above should not be taken as an unabashed denigration of mainstream studies. Indeed, a great deal of the work that we have highlighted has been extremely useful in driving the field forward, and in advancing our understanding of the dynamics that make British politics work. Yet, it remains our central contention that if the field of British politics itself is to meet the challenges of the 21st century and regain its status as a central area of enquiry, then there are several areas in which academics will have to raise their game. Here, then, we briefly highlight three themes, which, in our view, might be taken as starting points for the development of a more robust, rigorous, and dynamic field of debate.

\section{No more 'island mentality'}

The first issue that needs to be addressed is that of fostering a greater sense of disciplinary cohesion and identity within the British politics community itself. While of course this needs to include the core institutions, actors, and processes of the British state, it also needs to adopt a broader sense of disciplinary boundaries, and to construct an even-broader definition of 'the political' in order to include wider political processes than those that are usually conceived as being of central importance. Indeed, even a cursory glance around the broader field of British political science reveals that although those specialising in 'British politics' as defined in its traditional sense may well tend to be concentrated in a relatively small number of university departments, there is nevertheless an enormous body of highly stimulating and often innovative work being produced from within a plurality of fields and disciplines, which is dedicated to understanding the broader 'politics' of Britain beyond those of the state level. Properly conceived then, 'British politics' needs to be seen as a broad, inherently diverse, and multi-disciplinary field of study, incorporating a range of sub-fields such as psephology, policy and institutional analysis, regional and cultural studies, political theory, political economy, historical inquiry, and social policy. Seen in this way, far from being a narrowly drawn and largely redundant area of academic inquiry, the study of British politics should be recognised for being as diverse, rich, and prolific a field of study, if not more so, than it has ever been. In this respect, it is our hope that by providing a forum explicitly designed to promote British political studies, this journal can in some way help to foster a greater degree of disciplinary cohesion, and can help to reverse some of the more negative effects of its fragmentation. 


\section{More theory please!}

The second key issue that needs to be highlighted relates to the need for more awareness of, and a greater sensitisation towards theoretical issues. Many of the theoretical approaches and developments outlined above continue to reside at the fringes of the field, and much mainstream analysis continues to suffer from a lack of theoretical application and methodological rigour. In combination with this, it is our belief that the British politics community could also benefit from a greater cross-fertilisation of ideas, research, and methodological insights both from within and beyond the field itself. Indeed, one of the enduring legacies of the Westminster model approach has been a tendency - the source of Greenleaf's (1983) oft-cited complaint about the overall lack of 'organising perspectives' within the discipline - for scholars to focus almost exclusively upon single aspects of the political system rather than tackle wider questions about the British polity in a holistic manner. While recognising the importance of research into specific aspects of British politics, it nevertheless needs to be recognised that such research is more useful, and indeed meaningful, if it is related to the field in a broader and fuller sense. In short, a central challenge (and a core aim of this journal) is to encourage the development of empirical research that is theoretically rigorous and informed, and to encourage the empirical application of theoretical analyses, or at least to encourage theorists to explicitly signify how their work could be applied in an empirical manner.

A related, and a similarly abiding, legacy of the Westminster model, has been the temptation for many authors to displace the formal governmental arena from the broader social and economic context in which political processes are played out. Whereas one might expect a plethora of, for example, Marxist approaches to counter this, and to provide a range of theoretical grand narratives, such critical analyses have generally remained on the fringes of the discipline, and have yet to penetrate the mainstream. One of the main problems stemming from this has been an overall neglect of the recognition of broader inequalities in power within Britain as a whole, and a marked absence of any serious critical instinct within the field. Whereas traditional scholars often sought to study the political elite in Britain in splendid isolation from other groups, the steady proliferation of pluralist analyses have, in contrast, been eager to portray British democracy as being in a relatively healthy and stable condition. What is most often missing from approaches to British politics then is a recognition of broader structural inequalities along the lines of class, race, and gender, which hamper access to, as well as influence, political institutions and processes.

As a result, the dominance of empiricist over theoretical approaches to the study of British politics has prevented the field from matching the more 
sophisticated and varied theoretical advances of other disciplines, where the introduction of post-positivist analyses have opened up the depth of academic debate, and have stimulated a proliferation of rich theoretical work. Sadly, the 'island mentality', which is infused into the study of British politics has meant that the discipline has, to date, retained a stubborn insularity from absorbing these types of theoretical and methodological advances, and has instead tended to rely on narrow heuristic devices designed to explain micro-level behaviour and developments. In this sense then, what has been too often neglected is a sufficient recognition of the broader 'politics' of Britain itself.

\section{A more nuanced and sophisticated grasp of continuity and change}

A further problem deriving from this lack of theoretical development has been a traditional bifurcation between historical and contemporary analyses, leading to an overall problem of capturing the relationship between continuity and change. Again, this is very much part of the legacy of the Westminster model, which is in itself predicated upon a particular Whig interpretation of British history as a unilinear, progressive, but piecemeal movement towards an ideal-type liberal democratic system. Underpinned by such a strong, normatively driven historical narrative, it is perhaps no surprise that the traditional approach to British politics has bequeathed the discipline with a highly problematic and, in many ways, static view of the British political tradition. Those authors, such as Greenleaf (1983) or Birch (1964), who have attempted to chart the development of the system, have tended to present a narrative based around a dialectical struggle between key ideas, which have endured and developed over centuries. For Greenleaf, this struggle was between libertarianism and collectivism, whereas for Birch, the modern British political system was the outcome of a balance between the ideas of representative and responsible government. While this struggle of ideas is acknowledged to have resulted in brief periods of instability, the overwhelming emphasis within this historical narrative is the persistence of stability, continuity and, central to most accounts, consensus among the political elite. Although many authors have bemoaned the persistence of a Whig narrative, it is only in very recent years that this notion of a relatively static and incremental, unilinear tradition has been seriously challenged.

However, the problem which the discipline has had traditionally in dealing with the question of history, runs deeper than this. The attachment of many authors to the idea of continuity in British political development has meant that dominant approaches have often struggled to adequately explain change. This is not to say that change is overlooked; rather, that there are few theoretical tools available to adequately capture the complexity of the relationship between continuity and change. As a result, in their attempts to 
capture new developments in policy and institutional change, many analyses, as noted earlier, present a simple, binary opposition between periods of change and continuity. Where change is identified, it is often caricatured and distorted into a picture that provides an exaggerated dualism between the past and the present.

Many of these dualisms have become embedded within narratives of British politics since the Thatcher governments, to which many authors held a normative desire to portray as the complete antithesis to previous administrations. As such, the conventional narrative of the post-war era is based on a highly simplistic picture made up of periods of stability and continuity that are punctuated by short, sharp crises, or 'turning points'. This has led to a somewhat arbitrary periodisation of Britain's political development in terms of a series of relatively autonomous and self-contained phases, namely a brief period of radical change under the Attlee government, followed by a long period of continuity and stasis during the so-called consensus years, another period of radical state transformation under Thatcher, followed by a period of neo-liberal consensus and continuity that endures to the present-day (see, e.g. Addison, 1975; Pimlott, 1989; Dutton, 1991; Kavanagh and Morris, 1994; Seldon, 1994; Kerr, 2001). Moreover, while attempts to situate Britain's political development within a broader genealogy of events have always been prevalent and, indeed, integral to the traditional approach, the overwhelming majority of research into British politics remains highly contemporaneous in its focus, and is to a large extent divorced from any wider historical context. In sum then, as a field of study, British politics has also become temporally fragmented, with much research remaining confined within the tight boundaries, narratives, and logics of a specific time frame, and making little attempt to produce potentially fruitful linkages to broader themes, issues, and trends that have endured over a longer historical period. ${ }^{6}$

\section{Conclusion}

The challenges that confront the study of British politics during the early years of the 21 st century have perhaps never been greater. Faced with an array of changes to the academic environment, scholars operating under the traditional banner of British politics have, over the past few years, witnessed a decline in the status, relative importance, and the internal coherence of the field. To a large degree, however, these problems have been self-inflicted. Having failed to engage sufficiently with the profusion of theoretical developments emerging throughout other disciplines, and having failed to surmount the historical legacy bequeathed by the Westminster model in terms of its Whiggish teleology and its narrow view of 'the political', scholars of British politics have inadvertently cultivated a series of 'island mentalities' that have allowed the 
field to be perceived as little more than a sub-branch of other, more prestigious disciplines within political science.

In short, this article has highlighted three main problems that will need to be addressed if this situation is to be rectified. Firstly, academics will need to promote a greater degree of disciplinary cohesion through the crossfertilisation of ideas and research in order to reverse the prevailing fragmentation of the field, and to encourage a greater sense of an overarching British politics identity. Secondly, scholars will need to embark on a greater engagement with theoretical issues, and to foster a closer integration between theoretical and empirical analysis in order to eschew the overly empiricist and descriptive tradition that has dominated affairs for too long. And thirdly, there needs to be a greater and more sophisticated degree of attention paid to metatheoretical issues concerning continuity and change, as well as a greater connection between historical and contemporary analyses in order to situate the present within the context of longer-term themes and developments. While all this poses a serious set of challenges for scholars within the British politics community, the alternative path, namely the continuation of academic decline, appears to be far less palatable. Despite our defensive openings, we at least remain confident that they will succeed.

\section{Notes}

1 We would like to thank Wyn Grant, David Baker, Stuart McAnulla, and David Marsh for observations and comments on earlier drafts of this paper.

2 While this is not to deny that a thriving British politics community continues to exist, we would nevertheless contend that this is being increasingly pushed to the margins of contemporary political science debates.

3 The 23 departments were: Birkbeck College, Birmingham, Bradford, Bristol, De Montford, Essex, Exeter, Hull, Keele, LSE, Manchester, Newcastle, Oxford, Reading, Sheffield, Sussex, Warwick, York, Glasgow, St Andrews, Strathclyde, Aberystwyth, and Queens University. Kings College, London, which focuses on war and defence studies, was not included in the analysis. For the 2001 RAE ratings, see http://www.hero.ac.uk.

4 Among the limited historiographical reviews of the field of British politics, see Tivey (1988), Gamble (1990), and Kavanagh (2003).

5 The publication of a host of introductory textbooks devoted to British politics has also added to the sense of an increasingly diverse field of study. See, for instance, Dearlove and Saunders (2000), Kavanagh (2000), Kingdom (2001), Budge et al. (2004), and Moran (2005).

6 Many analyses of contemporary developments, such as the character and impact of New Labour, for instance, are set within a comparative context in relation to 'Thatcherism'. See, for example, Driver and Martell (1998), Hay (1999), Coates and Lawler (2000), Heffernan (2001) and Seldon (2001).

\section{References}

Addison, P. (1975) The Road to 1945: British Politics and the Second World War, London: Cape. Anderson, P. (1964) 'Origins of the present crisis', New Left Review 23: 26-53. 
Archer, M. (1995) Realist Social Theory: The Morphogenetic Approach, Cambridge: Cambridge University Press.

Bagehot, W. (1867) The English Constitution, London: Watts.

Baggott, R. (1995) Pressure Groups Today, Manchester: Manchester University Press.

Baggott, R. (2000) Pressure Groups and the Policy Process, Sheffield: Sheffield Hallam University Press.

Barberis, P. (1996) The Elite of the Elite, Aldershot: Dartmouth.

Beer, S. (1965) Modern British Politics: A Study of Parties and Pressure Groups, London: Faber and Faber.

Beer, S. (1982) Britain Against Itself, London: Faber.

Bevir, M. and Rhodes, R.A.W. (2003) Interpreting British Politics, London: Routledge.

Bhaskar, R. (1986) Scientific Realism and Human Emancipation, London: Verso.

Birch, A.H. (1964) Representative and Responsible Government, London: George Allen \& Unwin.

Birch, A. (1984) 'Overload, ungovernability and delegitimation', British Journal of Political Science 14: 135-161.

Bogdanor, V. (1999) Devolution in the UK, Oxford: Oxford University Press.

Bogdanor, V. (2001) The English Constitution, Cambridge: Cambridge University Press.

Brittan, S. (1977) The Economic Consequences of Democracy, London: Temple Smith.

Budge, I., Crewe, I., McKay, D. and Newton, K. (2004) The New British Politics, (3rd edn). London: Pearson Education.

Bulpitt, J. (1986) 'The discipline of the new Democracy: Mrs Thatcher's', Domestic Statecraft', Political Studies 34(1): 19-39.

Bulpitt, J. (1996) 'The European Question: Rules, National Modernisation and the Ambiguities of Primat Der Innenpolitik', in D. Marquand and A. Seldon (eds.) The Ideas that Shaped Post-War Britain, London: Fontana, pp. 214-256.

Coates, D. (1980) Labour in Power?, New York: Longman.

Coates, D. (1994) The Question of UK Decline, London: Harvester Wheatsheaf.

Coates, D. and Lawler, P. (eds.) (2000) New Labour in Power, Manchester: Manchester University Press.

Collins, B. and Robbins, K. (eds.) (1990) British Culture and Economic Decline, London: Weidenfeld and Nicholson.

Curry, O. (2003) 'Get real: evolution as metaphor and mechanism', British Journal of Politics and International Relations 5(1): 112-117.

Dearlove, J. and Saunders, P. (2000) Introduction to British Politics (3rd edn). Cambridge: Polity Press.

Dicey, A.V. (1885 [1908]) Introduction to the Study of the Law of the Constitution, London: Macmillan.

Dowding, K. (2000) 'How not to use evolutionary theory in politics: a critique of Peter John', British Journal of Politics and International Relations 2(1): 72-80.

Drewry, G. and Butcher, T. (1988) The Civil Service Today, London: Basil Blackwell.

Driver, S. and Martell, L. (1998) New Labour: Politics after Thatcherism, Cambridge: Polity Press.

Dutton, D. (1991) British Politics Since 1945: The Rise and Fall of Consensus, Oxford: Blackwell.

English, R. and Kenny, M. (eds.) (2000) Rethinking British Decline, Basingstoke: Macmillan.

Fine, B. and Harris, L. (1985) The Peculiarities of the British Economy, London: Lawrence and Wishart.

Finer, S. (ed.) (1975) Adversary Politics and Electoral Reform, London: Anthony Wigram.

Foley, M. (1993) The Rise of the British Presidency, Manchester: Manchester University Press.

Foley, M. (2000) The British Presidency: Tony Blair and the Politics of Public Leadership, Manchester: Manchester University Press.

Gamble, A. (1974) The Conservative Nation, London: Routledge. 
Gamble, A. (1981) Britain in Decline: Economic Policy, Political Strategy and the British State, Boston: Beacon Press.

Gamble, A. (1988) The Free Economy and the Strong State, London: Macmillan.

Gamble, A. (1990) 'Theories of British Politics', Political Studies 38: 404-420.

Gamble, A. (1994) Britain in Decline: Economic Policy, Political Strategy and the British State, (4th edn) London: St Martin's Press.

Garner, R. and Kelly, R. (1998) British Political Parties Today, Manchester: Manchester University Press.

Geddes, A. (2004) The European Union and British Politics, London: Palgrave.

George, S. (1998) An Awkward Partner: Britain in the European Community, Oxford: Oxford University Press.

Giddens, A. (1985) The Constitution of Society, Cambridge: Polity Press.

Grant, W. (1995) Pressure Groups, Politics and Democracy in Britain, London: Harvester Wheatsheaf.

Grant, W. (2000) Pressure Groups and British Politics, Basingstoke: Macmillan.

Greenleaf, W.H. (1983) The British Political Tradition, 3 Volumes. London: Methuen.

Guttsman, W.L. (1963) The British Political Elite, London: MacGibbon and Kee.

Hall, P. (1986) Governing the Economy: The Politics of State Intervention in Britain and France, Cambridge: Polity Press.

Hall, P. (1993) 'Policy paradigms, social learning and the state: the case of economic policymaking in Britain', Comparative Politics 25(2): 275-296.

Hall, P.A. and Taylor, R.C.R. (1996) 'Political science and the three new institutionalisms', Political Studies 44(4): 936-957.

Hall, S. (1979) “The Great Moving Right Show', Marxism Today, January, reprinted', in S. Hall and M. Jacques (eds.) The Politics of Thatcherism, London: Lawrence and Wishart.

Hall, S. and Jacques, M. (eds.) (1983) The Politics of Thatcherism, London: Lawrence and Wishart. Hay, C. (1996) Re-Stating Social and Political Change, Buckinghamshire: Open University Press.

Hay, C. (1999) The Political Economy of New Labour, Manchester: Manchester University Press.

Hay, C. and Wincott, D. (1998) 'Structure, agency and historical institutionalism', Political Studies 46(5): 951-957.

Headey, B. (1975) British Cabinet Ministers, London: George Allen \& Unwin.

Heclo, H. and Wildavsky, A. (1974) The Private Government of Public Money, London: Macmillan.

Heffernan, R. (2001) Thatcherism and New Labour: Political Change in Britain, London: Palgrave.

Hennessy, P. (2000) The Prime Minister: The Office and its Holders Since 1945, London: Allen Lane.

Hobsbawm, E. (1981) The Forward March of Labour Halted?, Worcester: Blackwell.

Hogg, S. and Hill, J. (1995) Too Close to Call-Power and Politics: John Major in No. 10., London: Little Brown.

Ingham, G. (1984) Capitalism Divided? The City and Industry in British Social Development, London: MacMillan.

Ingle, S. (2000) The British Party System (3rd edn). London: Pinter.

Jennings, I. (1936) Cabinet Government, Cambridge: Cambridge University Press.

Jessop, B. (1990) State Theory: Putting Capitalist States in their Place, Cambridge: Polity Press.

Jessop, B., Bonnett, K., Bramley, S. and Ling, T. (eds.) (1988) Thatcherism: A Tale of Two Nations, Cambridge: Polity Press.

John, P. (1998) Analysing Public Policy, London: Cassell.

John, P. (1999) 'Ideas and interests; agendas and implementation: an evolutionary explanation of policy change in British local government finance', British Journal of Politics and International Relations 1(1): 39-62.

Judge, D. (1993) The Parliamentary State, London: Sage. 
Judge, D. (2004) 'Whatever happened to parliamentary democracy in the United Kingdom?' Parliamentary Affairs 57(3): 682-701.

Kavanagh, D. (1990) Thatcherism and British Politics: The End of Consensus?, Oxford: Oxford University Press.

Kavanagh, D. (2000) British Politics: Continuities and Change (4th edn). Oxford: Oxford University Press.

Kavanagh, D. (2003) 'British political science in the inter-war years: the emergence of the founding fathers', British Journal of Politics and International Relations 5(4): 594-613.

Kavanagh, D. and Morris, P. (1994) Consensus Politics, Oxford: Blackwell.

Kavanagh, D. and Seldon, A. (1999) The Power Behind the Prime Minister: The Hidden Influence of Number Ten, London: HarperCollins.

Kay, A. (2003) 'Evolution in political science: a reply to Kerr', British Journal of Politics and International Relations 5(1): 102-111.

Kerr, P. (2001) Post-war British Politics: From Conflict to Consensus, London: Routledge.

Kerr, P. (2002) 'Saved from extinction: evolutionary theorising, politics and the state', British Journal of Politics and International Relations 4(2): 330-358.

King, A. (1975) 'Overload: problems of governing in the 1970s', Political Studies 23: 284-296.

King, A. (1985) The British Prime Minister, London: Macmillan.

Kingdom, J. (2001) Government and Politics in Britain (3rd edn). Cambridge: Polity Press.

Laski, H.J. (1933) Democracy in Crisis, North Carolina: University of North Carolina Press.

Laski, H.J. (1938) Parliamentary Government in England, London: George Allen \& Unwin.

Low, S. (1907) The Governance of England, London: Fisher Unwin.

Lowell, A.L. (1908) The Government of England, London: Macmillan.

Mackenzie, R.T. (1955) British Political Parties, London: Heinemann.

Mackintosh, J.P. (1963 [1977]) The Politics and Government of Britain, London: Hutchinson.

Marsh, D. (ed.) (1998) Comparing Policy Networks, Buckinghamshire: Open University Press.

Marsh, D., Buller, J., Hay, C., Johnston, J., Kerr, P., McAnulla, S. and Watson, M. (1999) Postwar British Politics in Perspective, Cambridge: Polity Press.

Marsh, D. and Rhodes, R.A.W. (1992) Policy Networks in British Government, Oxford: Clarendon Press.

Marsh, D., Richards, D. and Smith, M. (2001) Changing Patterns of Governance in the UK: Reinventing Whitehall, London: Macmillan.

Marsh, D., Richards, D. and Smith, M. (2003) 'Towards an asymmetric power model of the British polity', Government and Opposition 38(3): 306-322.

Marshall, G. (1999) 'The Analysis of British Political Institutions', in J. Hayward, B. Barry and A. Brown. (eds.) The British Study of Politics in the Twentieth Century, Oxford: Oxford University Press, pp. 257-285.

McAnulla, S. (2006) British Politics: A Critical Introduction, London: Continuum.

Middlemas, K. (1979) Politics in Industrial Society: The Experiences of the British System Since 1911, London: Andre Deutsch.

Miliband, R. (1969) The State in Capitalist Society, London: Quartet.

Moran, M. (2005) Politics and Governance in the UK, London: Palgrave.

Morrison, J. (2001) Reforming Britain: New Labour, New Constitution, London: Pearson.

Muir, R. (1930) How Britain is Governed, London: Constable.

Nairn, T. (1964) 'The British political elite', New Left Review 23: 19-25.

Nairn, T. (1981) 'The crisis of the British state', New Left Review 130: 37-44.

Norris, P. (1995) 'The politics of electoral reform in Britain', International Political Science Review 16(1): 65-78.

O’Neill, M. (ed.) (2004) Devolution and British Politics, London: Pearson Education.

Overbeek, H. (1990) Global Capitalism and National Decline, London: Unwin Hyman. 
Pimlott, B. (1989) 'Is the postwar consensus a myth?' Contemporary Record 2(6): 12-14.

Rhodes, R. (1997) Understanding Governance: Policy Networks, Governance, Reflexivity and Accountability, Buckinghamshire: Open University Press.

Rhodes, R. and Dunleavy, P. (1995) Prime Minister, Cabinet and Core Executive, London: Macmillan.

Richards, D. and Smith, M. (2002) Governance and Public Policy in the United Kingdom, Oxford: Oxford University Press.

Richardson, J. and Jordan, A. (1979) Governing Under Pressure, Oxford: Martin Robertson.

Robins, L. (ed.) (1987) Political Institutions in Britain: Development and Change, London: Longmans.

Rose, R. (1979) 'Ungovernability: is there fire behind the smoke?' Political Studies 17(3): 351-370.

Sampson, A. (1982) The Changing Anatomy of Britain, London: Hodder and Staughton.

Sampson, A. (2004) Who Runs this Place? The Anatomy of Britain in the Twenty-First Century, London: John Murray.

Scott, J. (1991) Who rules Britain?, Cambridge: Polity Press.

Seldon, A. (1994) 'Consensus: a debate too long?' Parliamentary Affairs 47: 501-515.

Seldon, A. (ed.) (2001) The Blair Effect: The Blair Government 1997-2000, London: Little Brown.

Smith, M.J. (1999) The Core Executive in Britain, Basingstoke: Palgrave.

Tivey, L. (1988) Interpretations of British Politics: The Image and the System, London: Harvester Wheatsheaf.

Truman, D. (1951) The Governmental Process, New York: Alfred A. Knopf.

Ward, H. (1989) Evolution and regulation: economism rediscovered, Essex Papers in Politics and Government, no. 64.

Ward, H. (1997) 'The possibility of an evolutionary explanation of the state's role in modes of regulation', in J. Stanyer and G. Stokes (eds.) Contemporary Political Studies, Vol. 1, Exeter: Political Studies Association.

Watson, M. (1999) 'Globalisation and the Development of the British Political Economy', in D. Marsh, et al. (eds.) Postwar British Politics in Perspective, Cambridge: Polity Press, pp. 125-143.

Watts, D. (2000) British Electoral systems: Achieving a Sense of Proportion, Sheffield Hallam.

Webb, P. (2000) The Modern British Party System, London: Sage.

Weir, S. and Beetham, D (2002) Democracy Under Blair: A Democratic Audit of the UK, London: Routledge.

Weir, S. and Beetham, D. (1999) Political Power and Democratic Control in Britain, London: Routledge.

Wiener, M. (1981) English Culture and the Decline of the Industrial Spirit, Cambridge: Cambridge University Press.

Wilson, G. (1977) Special Interests and Policy-Making, London: Wiley. 